\title{
CLINICAL PREDICTORS OF N2 DISEASE IN THE SETTING OF A NEGATIVE COMPUTED TOMOGRAPHIC SCAN IN PATIENTS WITH LUNG CANCER
}

Kenji Suzuki, MD

Kanji Nagai, MD

Junji Yoshida, MD

Mitsuyo Nishimura, MD

Kenro Takahashi, MD

Yutaka Nishiwaki, MD
Objectives: Although preoperative cervical mediastinoscopy is absolutely indicated for patients with lung cancer in whom computed tomography demonstrates mediastinal nodal enlargement, the indications when the computed tomographic scan is negative are controversial. To determine the indications in patients with negative computed tomographic scans, we retrospectively studied patients with surgically resected lung cancer. Methods: Between 1992 and 1997, 379 patients with lung cancer who had clinical N0-1 disease underwent surgical resection of lung cancer. Mediastinal lymph nodes were pathologically examined for metastasis in all the patients. A clinical diagnosis of nodal involvement was determined on the basis of preoperative computed tomographic findings: that is, mediastinal or hilar lymph nodes $1.0 \mathrm{~cm}$ or larger in the shortest axis were diagnosed as metastatic. Univariate and multivariate analyses were performed to determine the relationships between 9 clinical factors and pathologically proven $\mathbf{N} 2$ disease. Results: Among the patients with clinical N0-1 disease, $68(17.9 \%)$ had pathologic N2 disease. Adenocarcinoma histology, large tumor dimension, and high serum carcinoembryonic antigen levels were significant predictors of pathologic N2 disease on the basis of multivariate analyses $(P<.05)$. When these factors were combined, $43 \%$ of adenocarcinomas larger than $2.0 \mathrm{~cm}$ with high serum carcinoembryonic antigen levels $(P<.001), 34.7 \%$ of adenocarcinomas with high serum carcinoembryonic antigen levels $(P<.001)$, $25.6 \%$ of adenocarcinomas larger than $2.0 \mathrm{~cm}(P=.009)$, and $31.1 \%$ of patients with high serum carcinoembryonic antigen levels and large tumor dimension $(P<.001)$ had pathologic N2 disease. Conclusion: Preoperative cervical mediastinoscopy should be considered in patients in whom computed tomography is negative for lung cancer and who have some pathologic N2 predictive factors. (J Thorac Cardiovasc Surg 1999;117:593-8)
$D$ reresectional diagnosis of mediastinal nodal involvement (N2) in patients with lung cancer is challenging. Although the positron emission tomographic scan has been reported to contribute to the diagnosis of

From the Division of Thoracic Oncology, National Cancer Center Hospital East, Kashiwa, Chiba, Japan.

Supported in part by a Grant-in-Aid for Cancer Research from the Ministry of Health and Welfare, Japan.

Received for publication April 10, 1998; revisions requested June 19, 1998; revisions received July 27, 1998; accepted for publication Oct 8, 1998 .

Address for reprints: K. Suzuki, MD, Division of Thoracic Oncology, National Cancer Center Hospital East, 6-5-1, Kashiwanoha, Kashiwa, Chiba, 277-8577 Japan.

Copyright (C) 1999 by Mosby, Inc.

0022-5223/99 $\$ 8.00+0 \quad \mathbf{1 2 / 1 / 9 5 0 1 9}$
N2 disease, ${ }^{1,2}$ mediastinoscopy remains the most popular diagnostic modality. Some investigators reported that mediastinoscopy should be performed in all patients with surgically resectable lung cancer, ${ }^{3-5}$ whereas others concluded that it should be performed only if mediastinal lymph nodes are swollen on chest computed tomography (CT). ${ }^{6-8}$ This controversy results from the low sensitivity and specificity of chest CT scan in the diagnosis of $\mathrm{N} 2$ disease. ${ }^{9,10}$ In an attempt to determine the indications for mediastinoscopy in lung cancer cases in which $\mathrm{CT}$ scan shows no mediastinal nodal enlargement, we retrospectively studied patients with surgically resected lung cancer and identified highrisk populations who had CT-negative but pathologically positive nodal involvement in the mediastinum. 
Table I. $N 2$ disease according to regional nodal stations $(n=102)$

\begin{tabular}{lrr}
\hline Regional nodal stations & No. & $\%$ \\
\hline Superior mediastinal nodes $(\mathrm{n}=66)$ & & \\
No. 1. Highest mediastinal & 13 & 13 \\
No. 2. Paratracheal & 6 & 6 \\
No. 3. Pretracheal & 40 & 39 \\
No. 4. Tracheobronchial angle & 49 & 48 \\
Aortic nodes (n = 28) & & \\
No. 5. Subaortic (aortopulmonary window) & 19 & 19 \\
No. 6. Para-aortic (ascending aorta) & 19 & 19 \\
Inferior mediastinal nodes (n = 32) & & \\
No. 7. Subcarinal & 29 & 28 \\
No. 8. Paraesophageal & 4 & 4 \\
No. 9. Pulmonary ligament & 1 & 1 \\
\hline
\end{tabular}

\section{Patients and methods}

Between August 1992 and April 1997, 440 patients with lung cancer underwent surgical resection at our institute. Mediastinal lymph nodes were pathologically examined for metastasis in all patients. Among them, 268 were male and 172 were female. Their ages ranged from 22 to 89 years, with a median of 63 years. All patients underwent thoracic CT scan before the operation. The CT experiments were carried out on an X-vision/SP (Toshiba, Tokyo, Japan), and 10-mm thick contiguous sections were used to evaluate N2 status. The clinical diagnosis of nodal involvement was determined by diagnostic radiologists and based on the CT findings: that is, mediastinal or hilar lymph nodes $1.0 \mathrm{~cm}$ or larger in the shortest axis were diagnosed as metastatic. ${ }^{11}$

Histologic typing was determined according to the World Health Organization classification. ${ }^{12}$ The stage of the disease was based on the TNM classification of the International Union Against Cancer. ${ }^{13}$ Multiple lung carcinomas and hilar in situ squamous cell carcinomas were excluded from the study. Patients undergoing less than lobectomy were also excluded from the study. Only patients undergoing complete mediastinal lymph node dissection were included. The mediastinal lymph node dissection was performed according to the methods described by Naruke and associates. ${ }^{14}$ All resected lymph nodes were formalin fixed and examined microscopically by standard hematoxylin and eosin stain. The number of dissected lymph nodes ranged from 4 to 86 , with an average of 29. The number of staff surgeons is four, and they generally perform mediastinal lymph node dissection in the same manner as described by Naruke. Nodal status during surgical resection was reported by each staff surgeon.

The median follow-up period for 352 patients who were alive was 27 months. The length of survival was defined as the interval in months between the day of surgical resection of lung carcinoma and the date of death due to any cause or last follow-up. The survivals were calculated by the Kaplan-Meier method, ${ }^{15}$ and univariate analyses were performed by means of the log rank test. Because the median potential follow-up time was less than 3 years, we calculated 2-year survivals.
Table II. Characteristics of pathologic N2 disease

\begin{tabular}{lccc}
\hline N2 disease & No. & $\begin{array}{c}\text { Survival } \\
(\%)^{*}\end{array}$ & P value ${ }^{\dagger}$ \\
\hline Total N2 disease & 102 & 55.2 & \\
$\quad$ Number of metastatic stations & & & \\
$\quad$ Single station & 51 & 59.9 & .69 \\
$\quad$ Multiple stations & 51 & 50.7 & \\
$\quad$ Number of metastatic nodes & & & \\
$\quad$ Single node & 18 & 68.4 & .26 \\
$\quad$ Multiple nodes & 84 & 52.3 & \\
$\quad$ Mode of metastasis & & & \\
$\quad$ Non-skip metastasis & 66 & 51.4 & .52 \\
$\quad$ Skip metastasis & 36 & 63.2 & \\
$\quad$ Clinical N status & & & \\
$\quad$ Clinical N0-1 & 68 & 63.0 & .013 \\
$\quad$ Clinical N2 & 34 & 37.4 & \\
$\quad$ Surgical N status & & & \\
$\quad$ Surgical N0-1 & 41 & 68.3 & .026 \\
$\quad$ Surgical N2 & 61 & 45.3 & \\
\hline
\end{tabular}

* Survival denotes 2-year survival, because the median follow-up time for patients alive was only 27 months.

$\dagger P$ value in the log-rank test.

The medical record of each patient was examined for age, gender, histologic tumor type (adenocarcinoma vs others), pack-years of smoking, maximum tumor dimension, side of tumor (left vs right), location of tumor (central vs peripheral), lobar distribution (upper/middle lobe vs lower lobe), clinical $\mathrm{N}$ status, serum carcinoembryonic antigen (CEA) level $(\geq 5.0$ vs $<5.0 \mathrm{ng} / \mathrm{mL}$ ) and serum squamous cell carcinoma antigen (SCC) ( $\geq 1.5$ vs $<1.5 \mathrm{ng} / \mathrm{mL}$ ) levels. Tumor located in the inner one third of the lung was described as central and the others as peripheral tumor. Univariate and multivariate analyses were performed by the logistic regression procedure $^{16}$ on Statistica 4.1J (Apple Computer, Inc.) with a Power Macintosh 8100/100AV to determine the relationship between several clinical factors and pathologic N2 status. In multivariate analyses, forward and backward stepwise procedures were used to determine the combination of factors that were essential in predicting pathologic $\mathrm{N} 2$ disease. The $\chi^{2}$ test was used to compare the probability of pathologic N2 disease between subgroups in patients with surgically resected lung cancer.

\section{Results}

The nature of the $\mathrm{N} 2$ disease is shown in Tables I and II. As shown in Table II, N2 disease could be stratified on the basis of either clinical or surgical $\mathrm{N}$ status. In short, the prognosis of clinical or surgical N2 disease was significantly poorer than that of clinical or surgical N0-1 disease, respectively.

Of the 440 patients, $102(23.2 \%)$ had pathologic N2 disease (Table III). There were 65 (34.6\%) patients with pathologic N2 disease among 188 patients with an 
Table III. Relationship between clinical features and presence of pathologic N2 disease among all patients with surgically resected lung cancer*

\begin{tabular}{|c|c|c|c|}
\hline & $\begin{array}{c}\text { No. of } \\
\text { patients }\end{array}$ & $\begin{array}{c}\text { Pathologic } \\
\text { N2 }\end{array}$ & Probability \\
\hline Total & 440 & $102(23.2)$ & - \\
\hline \multicolumn{4}{|l|}{ Age $(y) \ddagger$} \\
\hline Range & $22-84$ & - & \multirow[t]{2}{*}{.70} \\
\hline Median & 63 & - & \\
\hline \multicolumn{4}{|l|}{ Gender } \\
\hline Male & 268 & $61(25.6)$ & \multirow[t]{2}{*}{.80} \\
\hline Female & 172 & $41(23.8)$ & \\
\hline \multicolumn{4}{|l|}{ Pack-years smoking $\neq$} \\
\hline Range & $0-148$ & - & \multirow[t]{2}{*}{.017} \\
\hline Median & 25 & - & \\
\hline \multicolumn{4}{|l|}{ CEA (ng/mL) } \\
\hline$<5.0$ & 252 & 37 (14.6) & \multirow[t]{2}{*}{$<.001$} \\
\hline $5.0 \leq$ & 188 & $65(34.6)$ & \\
\hline \multicolumn{4}{|l|}{$\begin{array}{l}\text { Serum squamous cell } \\
\text { carcinoma antigen } \\
(\mathrm{ng} / \mathrm{mL})\end{array}$} \\
\hline$<1.5$ & 317 & $70(22.1)$ & \multirow[t]{2}{*}{.68} \\
\hline $1.5 \leq$ & 74 & $18(24)$ & \\
\hline \multicolumn{4}{|l|}{ Side of tumor } \\
\hline Left & 178 & $44(24.7)$ & \multirow[t]{2}{*}{.537} \\
\hline Right & 262 & $58(22.1)$ & \\
\hline \multicolumn{4}{|l|}{ Location of tumor } \\
\hline Central & 34 & $9(26.4)$ & \multirow[t]{2}{*}{.64} \\
\hline Peripheral & 406 & $93(22.9)$ & \\
\hline \multicolumn{4}{|l|}{ Lobar distribution } \\
\hline Upper or middle lobe & 293 & 73 (24.9) & \multirow[t]{2}{*}{.618} \\
\hline Lower lobe & 147 & 29 (19.7) & \\
\hline \multicolumn{4}{|l|}{ Tumor size $(\mathrm{cm}) \ddagger$} \\
\hline Range & $0.5-10$ & - & \multirow[t]{2}{*}{.003} \\
\hline Mean & 3.46 & - & \\
\hline \multicolumn{4}{|l|}{ Histology } \\
\hline Squamous & 93 & $20(21.5)$ & .67 \\
\hline Adenocarcinoma & 303 & $73(24.1)$ & \multirow[t]{2}{*}{.501} \\
\hline Others & 44 & $9(20)$ & \\
\hline \multicolumn{4}{|l|}{ Clinical N status } \\
\hline N0-1 & 379 & 68 (17.9) & \multirow[t]{2}{*}{$<.001$} \\
\hline N2 & 61 & $34(56)$ & \\
\hline
\end{tabular}

*Numbers in parentheses are percentages.

$\dagger$ Probability in univariate analyses in logistic regression model.

$\ddagger$ Entered as a continuous variable into the logistic regression model.

elevated serum CEA level $(\geq 5.0 \mathrm{ng} / \mathrm{mL})$, whereas 37 (14.6\%) patients among 252 with normal serum CEA level $(P<.001)$ had pathologic N2 disease $(\mathrm{pN} 2)$. Tumor size was one of the significant predictors of N2 disease in univariate fashion $(P=.003)$. Clinical N2 status was also a significant predictor of pathologic N2 disease $(P<.001)$ : 34 patients $(56 \%)$ had pathologic N2 disease among 61 patients with clinical N2 disease. In multivariate analyses, clinical N2 status and high serum CEA level were significant predictors of pathologic N2 disease $(P<.001$; Table IV).
Table IV. Multivariate analyses of factors that predict carrying N2 disease among all patients with surgically resected lung cancer

\begin{tabular}{lccc}
\hline Variables & Odds ratio & $95 \%$ CI & P value \\
\hline $\begin{array}{l}\text { Clinical N2 } \\
\text { Presence vs absence }\end{array}$ & 4.91 & $2.74-8.82$ & $<.001$ \\
$\begin{array}{lccc}\text { CEA }(\mathrm{ng} / \mathrm{mL}) \\
\geq 5.0 \mathrm{vs}<5.0\end{array}$ & 2.63 & $1.63-4.25$ & $<.001$ \\
\hline CI, Confidence interval. & & &
\end{tabular}

Table V. Relationship between surgical N status and pathologic $N$ status among patients with clinical NO-1 lung cancer $(n=379)$

\begin{tabular}{lccc}
\hline & \multicolumn{2}{c}{ Pathologic N status } & \\
\cline { 2 - 3 } & Pathologic & Pathologic & \\
Surgical N status & NO-1 & N2 & P value* \\
\hline Surgical N0-1 & 298 & 35 & $<.0001$ \\
Surgical N2 & 12 & 33 & \\
\hline
\end{tabular}

*P value in the $\chi^{2}$ test.

Among 379 patients with no mediastinal nodal swelling on CT scan (clinical N0-1 disease), there were $68(17.9 \%)$ patients with pathologic N2 disease. Nodal status at the time of surgery is shown in Table V. The surgeon could not detect lymph node metastases in 35 $(51 \%)$ of 68 patients with N2 disease. Univariate analyses in the regression model revealed an elevated serum CEA level $(>5.0 \mathrm{ng} / \mathrm{mL})$ and tumor size to be significant factors predictive of pathologic N2 disease in this population $(P<.001, P=.047$, respectively; Table VI). In multivariate analyses, tumor size, high serum CEA level, and adenocarcinoma histology were significant predictors of pathologic N2 disease $(P=.037, .001$, and .014, respectively; Table VII).

When these factors were combined, we found several subgroups in patients with clinical N0-1 disease that showed significantly high frequency of pathologically proven N2 disease (Table VIII). The probability of pathologic N2 disease in the patients with adenocarcinoma larger than $2.0 \mathrm{~cm}$ and an elevated serum CEA level was $43 \%$, and this high frequency was statistically significant compared with levels in the remaining patients with clinical N0-1 disease $(P<.001)$. Similarly, $46 \%$ of the patients with adenocarcinoma larger than $3.0 \mathrm{~cm}$ and a high serum CEA level $(P<.001), 35 \%$ of patients with adenocarcinoma and high serum CEA level $(P<.001)$, $25.6 \%$ of patients with adenocarcinoma larger than 2.0 $\mathrm{cm}(P=.009), 30 \%$ of those with adenocarcinoma larg- 
Table VI. Relationship between clinical features and presence of pathologic $\mathrm{N} 2$ disease in clinical NO-1 cases*

\begin{tabular}{|c|c|c|c|}
\hline & $\begin{array}{l}\text { No. of } \\
\text { patients }\end{array}$ & $\begin{array}{l}\text { Pathologic } \\
\quad \text { N2 }\end{array}$ & Probability \\
\hline Total & 379 & $68(17.9)$ & - \\
\hline \multicolumn{4}{|l|}{ Age $(y) \ddagger$} \\
\hline Range & $22-84$ & - & \multirow[t]{2}{*}{.59} \\
\hline Median & 63 & - & \\
\hline \multicolumn{4}{|l|}{ Gender } \\
\hline Male & 222 & 37 (16.7) & \multirow[t]{2}{*}{.525} \\
\hline Female & 157 & $31(19.7)$ & \\
\hline \multicolumn{4}{|l|}{ Pack-years smoking } \\
\hline Range & $0-148$ & - & \multirow[t]{2}{*}{.158} \\
\hline Median & 20 & - & \\
\hline \multicolumn{4}{|l|}{ CEA (ng/mL) } \\
\hline$<5.0$ & 230 & 27 (11.7) & \multirow[t]{2}{*}{$<.001$} \\
\hline $5.0 \leq$ & 149 & $41(27.5)$ & \\
\hline \multicolumn{4}{|l|}{$\begin{array}{l}\text { Serum squamous cell } \\
\text { carcinoma antigen } \\
(\mathrm{ng} / \mathrm{mL})\end{array}$} \\
\hline$<1.5$ & 280 & $48(17.1)$ & \multirow[t]{2}{*}{.56} \\
\hline $1.5 \leq$ & 59 & $12(20.3)$ & \\
\hline \multicolumn{4}{|l|}{ Side of tumor } \\
\hline Left & 150 & $26(17.3)$ & \multirow[t]{2}{*}{.809} \\
\hline Right & 229 & $42(18.3)$ & \\
\hline \multicolumn{4}{|l|}{ Location of tumor } \\
\hline Central & 27 & $3(11.1)$ & \multirow[t]{2}{*}{.33} \\
\hline Peripheral & 352 & $65(18.5)$ & \\
\hline \multicolumn{4}{|l|}{ Lobar distribution } \\
\hline Upper or middle lobe & 250 & $48(19.2)$ & \multirow[t]{2}{*}{.556} \\
\hline Lower lobe & 129 & $20(15.5)$ & \\
\hline \multicolumn{4}{|l|}{ Tumor size $(\mathrm{cm}) \ddagger$} \\
\hline Range & $0.5-10$ & - & \multirow[t]{2}{*}{.047} \\
\hline Mean & 3.27 & - & \\
\hline \multicolumn{4}{|l|}{ Histology } \\
\hline Squamous & 74 & $9(12)$ & .15 \\
\hline Adenocarcinoma & 270 & $54(20.0)$ & \multirow[t]{2}{*}{.104} \\
\hline Others & 35 & $5(14)$ & \\
\hline \multicolumn{4}{|l|}{ Clinical N status } \\
\hline No & 342 & $58(17.0)$ & \multirow[t]{2}{*}{.22} \\
\hline N1 & 37 & $10(27)$ & \\
\hline
\end{tabular}

*Numbers in parentheses are percentages.

$\dagger P$ value in univariate analyses in logistic regression model.

\#Entered as a continuous variable into the logistic regression model.

Table VII. Multivariate analyses of factors that predict pathologic $N 2$ disease in patients with lung cancer who have clinical NO-1 disease

\begin{tabular}{lccc}
\hline Variables & Odds ratio & $95 \%$ CI & P value \\
\hline $\begin{array}{l}\text { CEA }(\mathrm{ng} / \mathrm{mL}) \\
\geq 5.0 \text { vs }<5.0\end{array}$ & 2.87 & $1.65-4.98$ & $<.001$ \\
$\begin{array}{l}\text { Histology } \\
\text { Adenocarcinoma } \\
\quad \text { vs others }\end{array}$ & 2.37 & $1.19-4.69$ & .014 \\
$\begin{array}{l}\text { Tumor size* } \\
\text { * }\end{array}$ & 1.17 & $1.01-1.36$ & .037 \\
\hline
\end{tabular}

Table VIII. The probability of pathologic N2 disease in subgroups of clinical NO-1 disease with several risk factors*

\begin{tabular}{|c|c|c|c|}
\hline \multirow[b]{2}{*}{ Subgroup } & \multicolumn{3}{|c|}{ Pathologic } \\
\hline & No. & N2 & Probability $\dagger$ \\
\hline Total clinical N0-1 disease & 379 & 68 (17.9) & - \\
\hline \multicolumn{4}{|l|}{$\begin{array}{l}\text { Adenocarcinoma, } \\
\text { high serum CEA level, } \$ \\
\text { and tumor size }>2 \mathrm{~cm}\end{array}$} \\
\hline With all of the factors & 73 & $31(42.5)$ & $<.001$ \\
\hline With either of the factors & 298 & $37(12.4)$ & \\
\hline With neither of the factors & 8 & $0(0)$ & \\
\hline \multicolumn{4}{|l|}{$\begin{array}{l}\text { Adenocarcinoma, } \\
\text { high serum CEA level, } \\
\text { and tumor size }>3 \mathrm{~cm}\end{array}$} \\
\hline With all of the factors & 46 & $21(45.7)$ & $<.001$ \\
\hline With either of the factors & 315 & $46(14.6)$ & \\
\hline With neither of the factors & 18 & $1(5.6)$ & \\
\hline \multicolumn{4}{|l|}{$\begin{array}{l}\text { Adenocarcinoma } \\
\text { and high serum CEA level }\end{array}$} \\
\hline With both of the factors & 98 & $34(34.7)$ & $<.001$ \\
\hline With either of the factors & 223 & $27(12.1)$ & \\
\hline With neither of the factors & 58 & $7(12.1)$ & \\
\hline \multicolumn{4}{|l|}{$\begin{array}{l}\text { Adenocarcinoma } \\
\text { and }>2 \mathrm{~cm} \text { in tumor size }\end{array}$} \\
\hline With both of the factors & 180 & $46(25.6)$ & .009 \\
\hline With either of the factors & 186 & $21(11.3)$ & \\
\hline With neither of the factors & 13 & $1(7.7)$ & \\
\hline \multicolumn{4}{|l|}{$\begin{array}{l}\text { Adenocarcinoma } \\
\text { and }>3 \mathrm{~cm} \text { in tumor size }\end{array}$} \\
\hline With both of the factors & 99 & $29(29.3)$ & .019 \\
\hline With either of the factors & 243 & $35(14.4)$ & \\
\hline With neither of the factors & 37 & $4(10.8)$ & \\
\hline \multicolumn{4}{|l|}{$\begin{array}{l}\text { High serum CEA level } \\
\text { and }>2 \mathrm{~cm} \text { in tumor size }\end{array}$} \\
\hline With both of the factors & 119 & $37(31.1)$ & $<.001$ \\
\hline With either of the factors & 187 & $26(13.9)$ & \\
\hline With neither of the factors & 73 & $5(6.8)$ & \\
\hline \multicolumn{4}{|l|}{$\begin{array}{l}\text { High serum CEA level } \\
\text { and }>3 \mathrm{~cm} \text { in tumor size }\end{array}$} \\
\hline With both of the factors & 78 & $25(32.1)$ & .003 \\
\hline With either of the factors & 164 & $30(18.3)$ & \\
\hline With neither of the factors & 137 & $13(9.5)$ & \\
\hline
\end{tabular}

*Risk factors were following three factors based on multivariate analysis: adenocarcinoma histology, high serum CEA level, and large tumor size. Numbers in parentheses are percentages.

$\dagger \chi^{2}$ test.

\$Serum CEA level $\geq 5 \mathrm{ng} / \mathrm{mL}$.

er than $3.0 \mathrm{~cm}(P=.019), 31 \%$ of those with tumor larger than $2.0 \mathrm{~cm}$ with high serum CEA level $(P<.001)$, and $32 \%$ of those with tumor larger than $3.0 \mathrm{~cm}$ with high serum CEA level $(P=.003)$ had pathologic N2 disease significantly more frequently.

\section{Discussion}

We have shown the existence of subgroups of patients with lung cancer harboring a high probability of patho- 
logic N2 disease in whom CT did not demonstrate mediastinal nodal enlargement. We think that mediastinoscopy should be performed in these high-risk patients, since they might benefit from preoperative induction therapy. ${ }^{17}$ Although some investigators have reported that all patients with surgically resectable lung cancer should undergo mediastinoscopy, ${ }^{3-5}$ our results indicated that in more than $80 \%$ of those with clinical N0-1 disease the procedure would be unnecessary.

On the other hand, some researchers reported that mediastinoscopy should be considered in all patients with CT-demonstrated mediastinal nodal enlargement (clinical N2), since this factor is a strong predictor of pathologic N2 disease, to confirm the diagnosis. ${ }^{6-8}$ Our results were consistent with these previous reports. Both univariate and multivariate analyses showed that clinical N2 disease is a significant predictor of pathologic N2 disease. Patients with lung cancer who have mediastinal lymph node enlargement on chest CT scan should undergo cervical mediastinoscopy to confirm the diagnosis. However, false negative CT scanning rates have been reported to be $18 \%$ to $52 \% .^{9,10,18,19}$ The prognosis of patients undergoing surgical resection for clinical N0/pathologic N2 lung cancer has been poor, even though it is better than that of patients with clinical N2/pathological N2 lung cancer. ${ }^{6,20}$ The former subgroup of patients might also benefit from preoperative multimodal therapy. ${ }^{17}$ Therefore preresectional identification of patients with lung cancer who have CT-negative microscopic mediastinal involvement is important.

Mackenzie and Riley ${ }^{21}$ concluded that mediastinoscopy should be omitted in patients who have peripheral nodules smaller than $2.0 \mathrm{~cm}$ in diameter and a negative CT examination of the mediastinum. Although our results were consistent with their report, only $21.4 \%(59 / 276)$ of patients with clinical N0-1 lung cancer who had a tumor larger than $2.0 \mathrm{~cm}$ had pathologic N2 disease. This result suggests that about $80 \%$ of patients would undergo unnecessary mediastinoscopy even in this population. Therefore additional clinical predictors of pathologic N2 disease are necessary.

In clinical N0-1 cases, there were subgroups with a high probability of pathologic N2 disease. Multivariate analyses revealed that an elevated serum CEA level, adenocarcinoma histology, and tumor size were significant clinical predictors for pathologic N2 disease. The following subgroup of patients with clinical N0-1 disease was considered to include candidates for mediastinoscopy because of their significantly high probability of pathologic N2 disease: adenocarcinoma cases with a high serum CEA level or a maximum tumor dimension larger than $2.0 \mathrm{~cm}$, or both. Reed and
Sugarbaker ${ }^{17}$ reported that mediastinoscopy was relatively indicated for lesions located within the inner one third of the lung field. However, according to our results, the centrally located lung carcinoma did not necessarily associate with the presence of N2 disease.

In contrast, our results also showed that patients with clinical N0-1 lung cancer have a very low probability of having N2 disease. For the following population, preoperative mediastinoscopy would not be indicated; otherwise, more than $90 \%$ of patients would undergo unnecessary mediastinoscopy (Table VIII): (1) patients with non-adenocarcinoma $2.0 \mathrm{~cm}$ or less in size and normal serum CEA level and (2) patients with any lung carcinoma $2.0 \mathrm{~cm}$ or less in size and normal serum CEA level.

In conclusion, we have delineated subgroups of patients with clinical N0-1 lung cancer who have a high probability of pathologic N2 disease. Mediastinoscopy should be considered in these subgroups to preoperatively identify patients with minimal mediastinal lymph node involvement.

We thank Dr Satoshi Sasaki, Epidemiology and Biostatistics Division, National Cancer Center Research Institute East, for his technical support in statistical analyses. We also thank Professor J. Patrick Barron, International Medical Communications Center, Tokyo Medical College, for reviewing the English manuscript.

\section{REFERENCES}

1. Chin R Jr, Ward R, Keyes JW, Choplin RH, Reed JC, Wallenhaupt $S$, et al. Mediastinal staging of non-small-cell lung cancer with positron emission tomography. Am J Respir Crit Care Med 1995;152:2090-6.

2. Sasaki M, Ichiya Y, Kuwabara Y, Akashi Y, Yoshida T, Fukumura $\mathrm{T}$, et al. The usefulness of FDG positron emission tomography for the detection of mediastinal lymph node metastases in patients with non-small cell lung cancer: a comparative study with X-ray computed tomography. Eur J Nucl Med 1996;23:741-7.

3. Ginsberg RJ. Evaluation of the mediastinum by invasive techniques. Surg Clin North Am 1987;67:1025-35.

4. Coughlin M, Deslauriers J, Beaulieu M, Fournier B, Piraux M, Rouleau J, et al. Role of mediastinoscopy in pretreatment staging of patients with primary lung cancer. Ann Thorac Surg 1985; 40:556-60.

5. Van Schil PE, Van Hee RH, Schoofs EL. The value of mediastinoscopy in preoperative staging of bronchogenic carcinoma. $\mathrm{J}$ Thorac Cardiovasc Surg 1989;97:240-4.

6. Daly BD, Mueller JD, Faling LJ, Diehl JT, Bankoff MS, Karp DD, et al. N2 lung cancer: outcome in patients with false-negative computed tomographic scans of the chest. J Thorac Cardiovasc Surg 1993;105:904-10.

7. Dillemans B, Deneffe G, Verschakelen J, Decramer M. Value of computed tomography and mediastinoscopy in preoperative evaluation of mediastinal nodes in non-small cell lung cancer: a study of 569 patients. Eur J Cardiothorac Surg 1994;8:37-42.

8. Backer CL, Shields TW, Lockhart CG, Vogelzang R, LoCicero 
JD. Selective preoperative evaluation for possible N2 disease in carcinoma of the lung. J Thorac Cardiovasc Surg 1987;93:337-43.

9. Rendina EA, Bognolo DA, Mineo TC, Gualdi GF, Caterino M, Di Biasi C, et al. Computed tomography for the evaluation of intrathoracic invasion by lung cancer. J Thorac Cardiovasc Surg 1987;94:57-63.

10. Brion JP, Depauw L, Kuhn G, de Fracquen P, Friberg J, Rocmans, et al. Role of computed tomography and mediastinoscopy in preoperative staging of lung carcinoma. J Comput Assist Tomogr 1985;9:480-4.

11. Aronchick JM. CT of mediastinal lymph nodes in patients with non-small cell lung carcinoma. Radiol Clin North Am 1990;28: 573-81.

12. World Health Organization. Histological typing of lung tumors. 2nd ed. Geneva: World Health Organization; 1981.

13. Hermanek P, Sobin LH, editors. UICC TNM Classification of malignant tumours. 4th ed. Berlin: Springer-Verlag; 1992.

14. Naruke T, Suemasu K, Ishikawa S. Lymph node mapping and curability at various levels of metastasis in resected lung cancer. J Thorac Cardiovasc Surg 1978;76:832-9.

15. Kaplan EL, Meier P. Nonparametric estimation from incomplete observations. J Am Stat Assoc 1958;53:457-81.

16. Cox D. The analysis of binary data. London: Methuen; 1970.
17. Reed MF, Sugarbaker DJ. Mediastinal staging of lung cancer. In: Pass HI, Mitchel JB, Johnson DH, Turrisi AW, editors. Lung cancer: principles and practice. Philadelphia: Lippincott-Raven; 1996. p. 537-44

18. Patterson GA, Ginsberg RJ, Poon PY, Cooper JD, Goldberg M, Jones D, et al. A prospective evaluation of magnetic resonance imaging, computed tomography, and mediastinoscopy in the preoperative assessment of mediastinal node status in bronchogenic carcinoma. J Thorac Cardiovasc Surg 1987;94:679-84.

19. Daly BD Jr, Faling LJ, Bite G, Gale ME, Bankoff MS, Yangja JL, et al. Mediastinal lymph node evaluation by computed tomography in lung cancer: an analysis of 345 patients grouped by TNM staging, tumor size, and tumor location. J Thorac Cardiovasc Surg 1987;94:664-72.

20. Cybulsky IJ, Lanza LA, Ryan MB, Putnam JB Jr, McMurtrey MM, Roth JA. Prognostic significance of computed tomography in resected N2 lung cancer. Ann Thorac Surg 1992;54:5337.

21. Mackenzie JW, Riley DJ. Diagnostic procedures: mediastinal evaluation, scalene lymph node biopsy, mediastinoscopy, and mediastinotomy. In: Baue A, Geha A, Hammond G, Laks H, Naunheim K, editors. Glenn's thoracic and cardiovascular surgery. 5th ed. Norwalk: Appleton \& Lange; 1991. p. 162-3. 